\title{
Global observation project gets green light
}

Declan Butler, Brussels

Ministers from some 60 nations have signed up to a ten-year plan to build a unified, global Earth observation system.

The Global Earth Observation System of Systems (GEOSS) will work with existing agencies to distribute the data needed to address issues ranging from disaster mitigation and climate change to the management of water resources. It received formal backing at a meeting in Brussels on 16 February

The nations agreed to set up the system according to a ten-year plan developed by an ad hoc working group that was led by the United States, the European Commission, Japan and South Africa. The initial costs of the project, which will be agreed over the next two years, are estimated to be of the order of just tens of millions of dollars annually.

Last December's tidal waves in the Indian Ocean lent fresh impetus to the GEOSS proposal, its backers say. "The tsunami disaster has shown us just how important Earth observation can be, in providing data to support an immediate humanitarian response and subsequent reconstruction," says Janez Potočnik, the European Union's research commissioner.

If successfully implemented, GEOSS will coordinate the plethora of national and international agencies that already spend billions of dollars on Earth observation. And it will aim to provide more complete geographical coverage, on land, in the oceans, air and space, and over time.

Under the Brussels deal, a secretariat will be established at the World Meteorological Organization in Geneva, Switzerland. It will determine international formats for data and build agreements under which agencies share data for free, or exchange it at low cost. Ultimately, GEOSS is also intended to broker funding and international agreements for new Earth observation instruments and facilities.

The Brussels meeting was the first overseas outing for the new US commerce secretary, Carlos Gutierrez. He enthusiastically backed the project, saying it would give us "the pulse of the entire globe".

Some scientists have been worried that GEOSS, which was first proposed in 2003, would serve mainly as a discussion forum, and a bureaucratic one at that. But at the meeting, they said that the scientific potential of the project was growing. "Potentially, GEOSS could grow into the most significant initiative in Earth observation since the invention of satellites," says Heiko Balzter, head of Earth observation at the UK-based Climate and

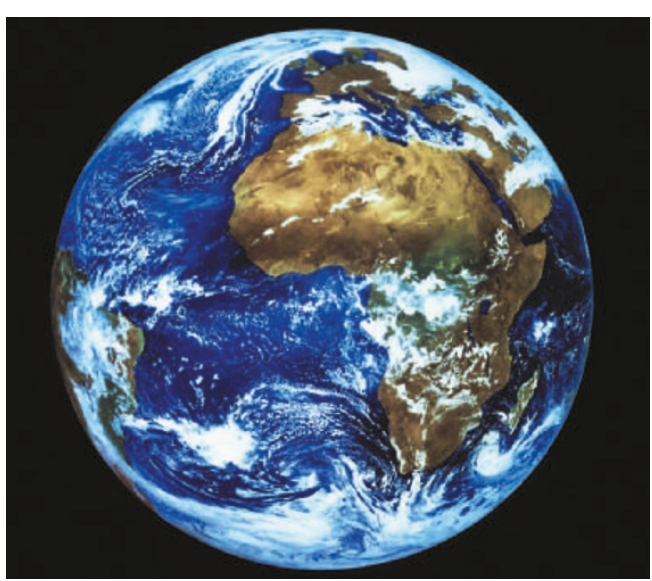

Think global: GEOSS will coordinate Earth observations.
Land-Surface Systems Interaction Centre.

The project's most immediate boon may be data that are free and easy to use. Dataaccess policies vary widely between countries and organizations. "The costs quickly add up," says David Rogers, an ecologist at the University of Oxford, who works on satellite forecasting of malaria. Data are also often available only after a delay, or in userunfriendly formats.

And such data can often be analysed only by experts, according to Paul Mason, former chief scientist at the UK Met Office and chair of the Global Climate Observing System (GCOS). "In cross-cutting programmes such as climate change, which require inputs from the land, ocean and atmospheric systems, it can be very difficult for individual research groups to use the data," he says, adding: "I hope GEOSS can change that."

Scientists also hope that the project will move Earth observation from a research activity to a more 'operational' footing, with services funded by governments worldwide, as for weather forecasting. "Basically, we need an operational system for climate observations," says Brian Hoskins, a climate modeller at the University of Reading, UK, and vicechairman of the scientific committee for the World Climate Research Programme.

The GCOS programme, which reports to the United Nations Framework Convention on Climate Change, has been developing plans for such a system. "I welcome this GEOSS big brother, which will have the political muscle to pursue some of the difficult things that need to be done," says Mason.

\section{Russian security arrests institute head for spying}

\section{Bryon MacWilliams, Moscow}

A senior Russian material scientist has been accused of selling state secrets to South Korea, in the latest of a string of arrests by the country's security services.

Oskar Kaibyshev, founder and director of the Institute for Metals Superplasticity Problems in Ufa, could be imprisoned for ten years if he is convicted. He says he is being accused of exporting dual-use technologies, which have both civilian and military applications, to a tyre manufacturer.

The 66-year-old researcher reported his own arrest on 18 February, telling news organizations that he had been questioned for some six hours on the previous day by agents of the Federal Security Service (FSB). He says that he has been suspended from his post at the institute, his bank accounts have been frozen, and he has been prohibited from leaving Ufa, which lies $1,500 \mathrm{~km}$ southeast of Moscow.

The interrogation focused on several years of collaboration between the institute and the tyre maker ASA, a subsidiary of Hankook Tire, which is based in Seoul. Kaibyshev says that the firm is using superplastic technology in its designs for high-pressure tyres. The technology stretches titanium alloy to enhance its mechanical properties and, according to Kaibyshev, can be used to produce spherical tanks that can be inflated to a pressure of 1,000 atmospheres.

The institute has not had access to state secrets for two decades, Kaibyshev told the Moscow-based radio station, Ekho Moskvy. "If you need to put somebody on trial, it should be agents of the FSB, who were fully informed of our contracts and should have warned us if there were any problems."

Ernst Chyorny, a member of the Public Committee for the Protection of Scientists - a Moscow-based human-rights group says that the technologies in question had already been exported to India in 1987, and to Italy in 1990 . They are also described in a forthcoming book co-authored by Kaibyshev. The book is being funded by the International Science and Technology Center, a Moscowbased project supported by, among others, the United States and the European Union. The centre helps military scientists from the former Soviet Union to find civilian work.

The FSB declined to comment, saying that it would release details of the charges against Kaibyshev next week. 